\title{
MOTIVASI SISWA KELAS XI IPA 1 DALAM MENGIKUTI PEMBELAJARAN PENDIDIKAN JASMANI BERBASIS ONLINE DI SMA ANGKASA 1 LANUD SOEWONDO
}

\author{
Rizki Bastanta B.Manalu ${ }^{1}$, Aser Paul Nainggolan ${ }^{2}$ \\ Pendidikan Olahraga, Universitas Quality Berastagi \\ Sumatera Utara, Indonesia \\ e-mail : bastanta.rizki@gmail.com
}

\begin{abstract}
Abstrak
Tujuan penelitian ini adalah menganalisis motivasi siswa kelas X1 IPA 1 dalam mengikuti pembelajaran pendidikan jasmani berbasis online di SMA Angkasa 1 Lanud Soewondo Medan. Pendekatan deskriptif kuantitatif digunakan pada penelitian ini, metode survei dan teknik pengambilan data menggunakan alat bantu berupa aplikasi google formulir. Populasi pada penelitian ini yaitu seluruh siswa kelas XI sebanyak 52 siswa. Jumlah sampel untuk penelitian ini sebanyak 32 orang siswa kelas XI IPA 1. Sampel diambil dengan menggunakan teknik simple random sampling. Analisis data dilakukan dengan menggunakan deskriptif kuantitatif yang dibuat dalam bentuk persentase. Data dikumpulkan melalui google formulir kemudian di validasi. Jika data tersebut valid, maka analisis data selanjutnya dapat dilakukan. Hasil penelitian dapat disimpulkan bahwa motivasi siswa kelas XI IPA 1 dalam mengikuti pembelajaran pendidikan jasmani berbasis online di SMA Angkasa 1 Lanud Soewondo termasuk dalam kategori sedang. Secara rinci, kategori tinggi sebanyak 9 orang $(28,13 \%)$, kategori sedang sebanyak 20 orang siswa $(62,50 \%)$, kategori rendah sebanyak 3 orang siswa $(9,38 \%)$.
\end{abstract}

Kata-kata kunci : motivasi, pendidikan jasmani, siswa

\begin{abstract}
The purpose of this study was to analyze the motivation of class X1 IPA 1 students in participating in online-based physical education learning at SMA Angkasa 1 Lanud Soewondo Medan. The quantitative descriptive approach was used in this research, the survey method and data collection techniques used a tool in the form of a google form application. The population in this study were all students of class XI as many as 52 students. The number of samples for this study were 32 students of class XI IPA 1. The sample was taken using simple random sampling technique. Data analysis was performed using quantitative descriptive in the form of a percentage. The data is collected through google form and then validated. If the data is valid, then further data analysis can be carried out. The results of the study concluded that the motivation of class XI IPA 1 students in participating in online-based physical education learning at SMA Angkasa 1 Lanud Soewondo was included in the medium category. In detail, the high category was 9 students (28.13\%), the medium category was 20 students (62.50\%), the low category was 3 students (9.38\%).
\end{abstract}

Keyword : motivation, physical education, students 


\section{PENDAHULUAN}

Pembangunan sumber daya manusia Indonesia yang berkualitas sangat penting dalam dunia pendidikan. Manusia yang berkualitas akan mendorong negara Indonesia dapat mengalami perkembangan dan maju. Menurut (Sudarsana, 2016), pembangunan manusia dilakukan dengan sadar, berencana dan juga berkesinambungan untuk menuju kearah perubahan dan mengalami kemajuan, sehingga akan mencapai titik sempurna. Lebih lanjut dikatakan untuk sektor pendidikan berperan penting untuk mencapai tujuan kualitas manusia yang sempurna.

Pendidikan adalah aktivitas yang sengaja untuk dilakukan oleh peserta didik. Sikap dan kepribadian baik dimiliki oleh peserta didik, sehingga dalam penerapan yang dilakukan oleh sekolah telah disesuaikan dengan sistem pendidikan secara nasional. Oleh karena itu, pengembangan pendidikan oleh siswa diperoleh dari sekolah. Menurut (Fauziah, Rosnaningsih dan Azhar, 2017) menyatakan bahwa sekolah merupakan lembaga pendidikan formal. Dalam kegiatannya, sekolah diharuskan untuk mampu mengembangkan potensi yang dimiliki oleh peserta didik. Sekolah dianggap sebagai lembaga yang bersifat kompleks dan unik. Arti kata bersifat komplek yaitu sekolah sebagai organisasi yang saling berkaitan dan saling menunjang. Sedangkan bersifat unik dikarenakan memiliki karakteristik tersendiri dalam proses belajar mengajar, sebagai wadah penyelenggara kegiatan dalam meningkatkan kualitas dan potensi yang ada pada peserta didik.

Pendidikan jasmani adalah bagian dari pendidikan yang dilakukan melalui pengembangan individu. Pendidikan jasmani disekolah diberikan untuk merangsang pertumbuhan dan perkembangan jasmani siswa.
(Rokhayati, 2016), program pendidikan jasmani disekolah dilakukan untuk melihat potensi peserta didik, kemudian potensi tersebut dikembangkan. Proses pendidikan jasmani mengutamakan elaborasi yang dihubungkan dengan sisi sosial-emosional, kognitif reflektif, keterampilan gerak dan psikologis peserta didik. Melalui pendidikan jasmani diharapkan siswa dapat menopang kualitas belajar disekolah menjadi lebih bersemangat.

Motivasi merupakan perubahan yang terjadi dalam diri seseorang. Perubahan ditandai dengan suatu dorongan yang berasal dari dalam diri untuk dapat mencapai tujuan yang telah ditetapkan. Adapun dorongan dan reaksi yang ditimbulkan bisa dikarenakan oleh kebutuhan akan prestasi didalam kehidupan. Sehingga dorongan dan keinginan menjadi sebuah usaha dalam mencapai hasil belajar yang tinggi (Muhammad, 2017).

Motivasi berupa dorongan secara sadar dan tidak sadar yang dilakukan oleh seseorang dalam kegiatan untuk mencapai tujuan. Motivasi dapat berasal dari dalam diri, guru, teman dan juga keluarga. Siswa yang memiliki motivasi belajar maka akan serius dan tertarik dalam pembelajaran sehingga siswa mendapatkan hasil belajar yang memuaskan, tetapi siswa yang tidak memiliki motivasi belajar maka akanselalu merasa bosan dalam pembelajaran. Dalam proses pembelajaran, motivasi diibaratkan sebagai bahan bakar untuk menghidupkan mesin. Motivasi belajar yang memadai dapat mendorong siswa untuk berprilaku aktif sehingga akan dapat berprestasi didalam kelas atau diluar kelas. Akan tetapi, motivasi yang terlalu berlebihan dapat mengakibatkan dampak negatif terhadap keefektifan siswa dalam belaajar. 
Guru dituntut untuk selalu profesional, artinya guru diharuskan untuk menggali kemampuan siswa melalui pemberian motivasi. Akan tetapi, pelajaran yang berbeda akan menjadikan kesulitan tersendiri bagi siswa. Sehingga menjadikan tantangan bagi guru untuk bersikap professional untuk menjalankan tugas. Keaktifan guru memberikan motivasi akan berdampak bagi siswa agar bersemangat dan bergairah dalam mengikuti pembelajaran.

Situasi yang sedang dialami seluruh dunia termasuk Indonesia yaitu situasi dimana telah terjadi suatu kasus penyebaran virus yang berasal dari China yang disebut juga dengan Corona virus Disease 2019 (COVID-19). Situasi yang tengah berlangsung pada tahun 2019 ini semakin mengalami peningkatan orang yang terkena virus. Sehingga pemerintah mengambil langkah untuk mencegah penyebaran virus diberbagai sektor termasuk didalamnya. Alternatif pembelajaran yang dilakukan yaitu melalui pemanfaatan teknologi informasi.

SMA Angkasa 1 Lanud Soewondo Medan merupakan salah satu sekolah swasta yang ada di Provinsi Sumatera Utara. Siswa di SMA Angkasa 1 Lanud Soewondo Medan selama menjalankan pembelajaran berbasis online, aplikasi yang digunakan guru dalam memberikan materi pelajaran melalui google classroom dan zoom. Penelitian terdahulu dilakukan oleh (Hapsari dan Pamungkas, 2019) penggunaan media pembelajaran dengan memanfaatkan google classroom, dimana melalui akses tersebut pendidik dapat dengan mudah mengakses aplikasi dikarenakan gratis. Selain itu juga, penelitian lain bahwa media baru dalam dunia pendidikan akan dapat menghasilkan proses yang lebih mudah dalam penyelesaian hasil proses pembelajaran. Penggunaan aplikasi digital akan mempermudah dalam komunikasi. Sedangkan penelitian lain dilakukan oleh (Soni et al., 2018), dengan penggunaan google classroom dalam kegiatan pembelajaran akan dapat menjadi efektif, jika guru dan siswa dapat mengikuti kegiatan pembelajaran secara tatap muka dengan google classroom. Selain itu juga, untuk menggunakan zoom sebagai aplikasi menjelaskan materi dalam bentuk video atau langsung menshare materi kepada siswa dalam pertemuan pembelajaran secara online.

Zoom dimanfaatkan juga dalam pembelajaran berbasis online. Menurut (Jannah, 2014), hasil penelitian ditemukan bahwa dengan pengaplikasian zoom sebagai pendukung pembelajaran online ratarata hasil belajar siswa lebih tinggi jika dibandingkan dengan tanpa menggunakan aplikasi zooming presentation. Berdasarkan latar belakang tersebut, maka peneliti tertarik untuk mengetahui motivasi siswa kelas XI IPA1 SMA Angkasa 1 Lanud Soewondo Medan dalam mengikuti pembelajaran berbasis online khususnya pada pembelajaran pendidikan jasmani.

\section{Motivasi}

Motivasi adalah suatu dorongan dalam diri seseorang untuk dapat mencapai tujuan yang direncanakan. Definisi motivasi menurut Mc. Donald bahwa motivasi yaitu terjadinya perubahan energy yang berasal dari diri seseorang yang ditandai dengan munculnya "feeling" yang diawali dengan membuat tujuan (Sadirman, 2011). Penelitian ini juga menemukan bahwa motivasi merupakan dorongan yang dilakukan oleh individu yang dilakukan secara sengaja untuk suatu tujuan tertentu. 
hat yang saling berkaitan dan mempengaruhi. Belajar adalah tingkah laku yang mengalami perubahan dan cenderung relative permanen serta berpotensi untuk dapat terjadi secara potensial untuk mencapai hasil praktik berdasarkan tujuan yang dibuat. Motivasi belajar dapat ditimbulkan karena dua faktor yaitu faktor intrinsik dan faktor ekstrinsik. Faktor intrinsik yaitu hasrat dan keinginan untuk kebutuhan akan belajar, harapan dan cita-cita. Sedangkan faktor ekstrinsik yaitu berupa penghargaan, lingkungan bekerja yang bersifat kondusif dan kegiatan yang dianggap untuk menarik (Uno, 2014). Motivasi belajar adalah kondisi psikologi untuk mendorong seseorang untuk dapat belajar (Syah, 2010).

Motivasi dapat dilihat dari sisi
$\begin{aligned} & \text { kejiwaan untuk mengalami } \\ & \text { perkembangan. }\end{aligned}$ Artinya dapat terpengaruh terhadap kondisi fisiologis dan kemampuan untuk kematangan psikologis siswa dalam belajar. Menurut Dimyati dan Mudjiyono (2009), menyatakan bahwa terdapat beberapa unsur yang dapat berpengaruh terhadap motivasi siswa dalam belajar, seperti (a) adanya cita-cita dan aspirasi yang berasal dari siswa. Melalui cita-cita akan dapat meningkatkan motivasi belajar siswa baik secara faktor ekstrinsik dan faktor intrinsik; (b) kemampuan siswa berupa keinginan siswa berdasarkan kemampuan dan kecakapan untuk mencapai keinginan; (c) kondisi siswa berasal dari kondisi jasmani dan rohani yang akan berdampak pada motivasi belajar; (d) lingkungan siswa berupa keadaan alam, lingkungan tempat tinggal, cara bergaul siswa dan juga kehidupan dalam bermasyarakat (Kompri, 2015).

Kegiatan pembelajaran di sekolah berperan dalam motivasi baik secara instrinsik dan ekstrinsik dianggap berperan penting. Melalui motivasi, siswa diharapkan mampu untuk mengembangkan segala aktivitas dan berinisiatif untuk dapat diarahkan pada pemeliharaan dan ketekunan dalam proses pembelajaran. Ada beberapa bentuk dan cara untuk menumbuhkan motivasi dalam kegiatan belajar disekolah" (Sadirman, 2011) yaitu : memberi angka, hadiah, kompetensi, Ego-Invholvement, memberi ulangan, meberitahu hasil, pujian, hukuman, hasrat untuk belajar, minat dan tujuan yang diakui.

\section{Pembelajaran Berbasis Online}

Proses

pembelajaran menggunakan elektronik atau juga disebut dengan e-learning. Pembelajaran e-learning telah dimulai sejak tahun 1970-an (Waller dan Wilson, 2001) dalam (Adawi, 2008). Konsep dalam pembelajaran berbasis jaringan dan komputer yaitu suatu bentuk pembelajaran dengan menggunakan model dengan memanfaatkan teknologi web dan internet. Konsep dalam pembelajaran dan pengajaran bukan sesuatu hal yang baru baik dalam ide maupun dalam pemikiran, sehingga berkembang sejak pada dasawarsa dahulu.

Media pembelajaran berbasis online berarti pemanfaatan media dengan menggunakan alat control yang dapat dioperasikan dengan menggunakan user (pengguna), sehingga user dapat mengendalikan dan mengakses kebutuhan pengguna, seperti mampu mengunduh berbagai sumbersumber untuk materi Tenses pada pelajaran Bahasa Inggris. Keuntungan penggunaan media pembelajaran online adalah pembelajaran bersifat mandiri dan interaktivitas yang tinggi, mampu meningkatkan tingkat ingatan, memberikan lebih banyak pengalaman 
belajar, dengan teks, audio, video dan animasi yang semuanya digunakan untuk menyampaikan informasi, dan juga memberikan kemudahan menyampaikan, meng-update isi, mengunduh, para siswa juga bisa mengirim email kepada siswa lain, mengirim komentar pada forum diskusi, memakai ruang chat, hingga link video conferenceuntuk berkomunikasi langsung (Arnesti dan Hamid, 2015).

\section{METODE}

Jenis pada penelitian ini yaitu penelitian deskriptif. Penelitian mendiskripsikan pengaruh google classroom terhadap motivasi belajar siswa di sekolah.

Desain pada penelitian ini adalah One Shot Case Study, dimana subjek diperlakukan untuk diamati ketika melakukan penerapan perlakukan dan melakukan pengukuran terhadap akibat dari perlakukan. Adapun perlakuan yang dimaksud yaitu pembelajaran dengan menggunakan google classroom untuk dapat melihat pengaruh dari motivasi terhadap motivasi belajar dari pada siswa.

Kegiatan penelitian dilaksanakan pada mulai semester genap 2019/2020 pada siswa kelas XII IPA 1 di SMA Angkasa 1 Lanud Soewondo sebanyak 32 orang.

Adapun instrument yang digunakan dalam penelitian ini berupa tes hasil belajar siswa dan lembar angket motivasi belajar siswa. Setelah kedua instrument yang akan digunakan dilakukan validasi untuk pelaksanaan penelitian.

Teknik pengumpulan data merupakan suatu cara yang digunakan oleh peneliti untuk dapat memperoleh suatu infomrasi yang akan dibutuhkan untuk mencapai tujuan penelitian. Oleh karena itu teknik pengumpulan data penelitian ini yaitu dengan dokumentasi, tes, angket dalam bentuk google formulir dan hasil belajar siswa. Adapun kategori penelitian ini merujuk pada skala likert dapat dilihat pada tabel 1.

Tabel 1. Kriteria Hasil Belajar

\begin{tabular}{cc}
\hline $\begin{array}{c}\text { Tingkat } \\
\text { Penugasan }\end{array}$ & Kategori \\
\hline $76-100$ & Tinggi \\
$51-75$ & Sedang \\
$26-50$ & Rendah \\
$0-25$ & Sangat Rendah \\
\hline
\end{tabular}

Ketuntasan pada penelitian hasil belajar 70. Setelah itu, skor hasil belajar akan dikategorikan kedalam bentuk persentasi dengan menggunakan rumus

Dimana :

$$
P=\frac{f}{N} X 100 \%
$$

$\mathrm{P} \quad$ : Persentase
$\mathrm{f} \quad$ : Frekuensi yang dicari
persentase
$\mathrm{N} \quad$ Jumlah subjek (sampel)

Untuk motivasi belajar siswa, maka digunakan rumus berikut:

$\%$ PRMke $-i=\frac{\text { NRM ke }-i}{\text { NRM maksimum }} \times 100 \%$

Dimana :

\%PRM ke-i : persentase nilai respons mahasiswa pada item pernyataan ke- $i$

NRM ke-i : total nilai respons mahasiswa pada item pernyataan ke-

NRM $: 5 n$

maksimum $=$ $n \quad$ (banyak siswa) $\times 5$

(skor tertinggi) 
t-tes dimaksudkan untuk menguji hipotesis penelitian mengenai ada tidaknya perbedaan motivasi belajar siswa setelah mengikuti pembelajaran google classroom di SMA Angkasa 1 Lanud Soewondo. Uji t-test menggunakan SPSS 16 for windows. Tingkat signifikan yang digunakan $\alpha=$ 0,05 dengan kriteria adalah tolak Ho jika thitung $\geq \mathrm{t}$ table dan diterima Ho jika thitung $\leq$ ttabel, nilai sig. $\leq \alpha$ maka tolak Ho

\section{HASIL DAN PEMBAHASAN}

Penelitian ini dilaksanakan di SMA Angkasa 1 Lanud Soewondo. Sekolah ini berada di Kota Medan Provinsi Sumatera Utara. Subjek yang diuraikan dalam penelitian ini adalah seluruh siswa kelas XI IPA 1 di SMA Angkasa 1 Lanud Soewondo yang berjumlah 32 responden. Waktu penelitian ini dilaksanakan pada hari Jumat-Selasa tanggal 08-11 Mei 2020. Pengambilan data penelitian dilakukan secara online dengan menggunakan google formulir. Tahapan yang dilakukan yaitu pembuatan daftar pertanyaan dalam bentuk pilihan jawaban berisikan faktor intrinsik dan faktor ekstrinsik. Profil responden berdasarkan jenis kelamin dapat dilihat pada Tabel 2.

Tabel 2. Profil Jenis Kelamin Responden

\begin{tabular}{clcc}
\hline No & $\begin{array}{c}\text { Jenis } \\
\text { Kelamin }\end{array}$ & Orang & $\begin{array}{c}\text { Persentasi } \\
(\mathbf{\%})\end{array}$ \\
\hline 1. & Laki-laki & 21 & 65,63 \\
2. & Perempuan & 11 & 34,38 \\
\hline & Total & 32 & 100,00 \\
\hline
\end{tabular}

Tabel 2 menunjukkan bahwa siswa di SMA Angkasa 1 Lanud Soewondo berjenis kelamin laki-laki lebih besar dibandingkan dengan siswa perempuan. Responden siswa laki-laki sebanyak 21 orang $(65,63 \%)$, sedangkan responden siswa perempuan sebanyak 11 orang $(34,38 \%)$. Selanjutnya pada Tabel 3 menunjukkan tingkat usia responden siswa yang dapat dilihat pada tabel dibawah ini.

Tabel 3. Profil Usia Responden

\begin{tabular}{cccc}
\hline No & $\begin{array}{c}\text { Usia } \\
\text { (Tahun) }\end{array}$ & Orang & $\begin{array}{c}\text { Persentasi } \\
(\mathbf{\%})\end{array}$ \\
\hline 1. & $15-16$ & 21 & 65,63 \\
2. & $17-18$ & 11 & 34,38 \\
\hline & Total & 32 & 100,00 \\
\hline
\end{tabular}

Tabel 3, profil usia responden dengan kategori usia 15-16 tahun sebanyak 21 orang $(65,63 \%)$, usia $17-18$ sebanyak 11 orang $(34,38 \%)$. Jadi dapat disimpulkan bahwa profil responden berdasarkan usia terbanyak yaitu pada usia 15-16 tahun.

\section{Motivasi Siswa Dalam Mengikuti Pembelajaran Pendidikan Jasmani Berbasis Online}

Media pembelajaran berbasis online berarti pemanfaatan media dengan menggunakan alat kontrol yang dapat dioperasikan dengan menggunakan user (pengguna), sehingga user dapat mengendalikan dan mengakses kebutuhan pengguna, seperti mampu mengunduh berbagai sumbersumber untuk materi Tenses pada pelajaran Bahasa Inggris. Keuntungan penggunaan media pembelajaran online adalah pembelajaran bersifat mandiri dan interaktivitas yang tinggi, mampu meningkatkan tingkat ingatan, memberikan lebih banyak pengalaman belajar, dengan teks, audio, video dan animasi yang semuanya digunakan untuk menyampaikan informasi, dan juga memberikan kemudahan menyampaikan, meng-update isi, mengunduh, para siswa juga bisa mengirim email kepada siswa lain, mengirim komentar pada forum diskusi, 
memakai ruang chat, hingga link video conferenceuntuk berkomunikasi langsung (Arnesti dan Hamid, 2015).

Penelitian ini merupakan penelitian deskriptif, sehingga keadaan objek akan digambarkan sesuai dengan data yang diperoleh. Dari hasil penelitian tentang motivasi siswa kelas XI IPA 1 dalam mengikuti pembelajaran pendidikan jasmani di SMA Angkasa 1 Lanud Soewondo Medan, perlu dideskripsikan secara keseluruhan maupun secara masingmasing dari faktor-faktor maupun indikator yang mendasari motivasi siswa kelas XI IPA 1 dalam mengikuti pembelajaran pendidikan jasmani berbasis online. Faktor-faktor untuk motivasi siswa kelas XI IPA1 dalam mengikuti pembelajaran pendidikan jasmani berbasis online pada SMA Angkasa 1 Lanud Soewondo adalah faktor intrinsik dan faktor ekstrinsik.

Mediawati (2010) bahwa peningkatan kualitas penyelenggaraan pembelajaran tersebut memiliki peranan sentral dalam upaya mewujudkan peningkatan mutu pendidikan secara berkelanjutan. Mutu pendidikan pada saat ini menggunakan prestasi belajar peserta didik sebagai ukuran untuk menunjukan keberhasilannya. Ini berarti berhasil tidaknya proses pendidikan dapat ditunjukan oleh tinggi rendahnya prestasi belajar peserta didik. Oleh karena itu, setelah mengalami proses pendidikan dalam jangka waktu tertentu semua peserta didik diharapkan menunjukan perilaku positif sebagai prestasi belajar.

Berdasarkan analisa deskriptif yang diolah dengan menggunakan bantuan SPSS versi 17 for windows, untuk variabel Motivasi Siswa dapat diketahui rerata (Mean) yaitu 51.43 median (Me) yaitu 51 dan standar deviasi yaitu 5,12. Berdasarkan angket Motivasi Belajar yang disebar dapat diketahui pula skor maksimal untuk variabel Motivasi yaitu 68 dan skor minimal yaitu 45,5. Selanjutnya data dikategorikan menjadi 4 kategori, yaitu kategori sangat rendah, rendah, sedang, dan tinggi berdasarkan nilai mean ideal dan standar deviasi ideal. Tabel 4 merupakan penghitungan norma kategori motivasi siswa kelas XI IPA 1 dalam mengikuti pembelajaran pendidikan jasmani berbasis online di SMA Angkasa 1 Lanud Soewondo. Tabel 4. Descriptive Motivasi Siswa

\begin{tabular}{lrrrrr}
\hline & N & Minimum & Maximum & Mean & \multicolumn{1}{c}{ Std. Deviation } \\
\hline MOTIVASI & 32 & 45.50 & 68.00 & 51.4375 & 5.12544 \\
Valid N & 32 & & & & \\
(listwise) & 32 & & & & \\
\hline
\end{tabular}

Dari hasil deskriptif setiap variabel ke peneliti membuat distribusi frekuensi variabel motovasi siswa menjadi 5 kelas interval Berikut tabel distribusi frekuensi untuk variabel motivasi belajar siswa dapat dilihat pada Tabel 4 . 
Tabel 5. Distribusi Frekuensi Variabel Motivasi Siswa Mengikuti Pembelajaran Online

\begin{tabular}{rrrrrr}
\hline & Frequency & Percent & Valid Percent & Cumulative Percent \\
\hline Valid & $45-50$ & 4 & 12.5 & 12.5 & 12.5 \\
& $51-56$ & 16 & 50.0 & 50.0 & 62.5 \\
& $57-62$ & 9 & 28.1 & 28.1 & 90.6 \\
& $57-62$ & 1 & 3.1 & 3.1 & 93.8 \\
& 5 & 2 & 6.2 & 6.2 & 100.0 \\
& Total & 32 & 100.0 & 100.0 & \\
\hline
\end{tabular}

Berdasarkan distribusi frekuensi dapat digambarkan histogram dapat dilihat pada Gambar 1.

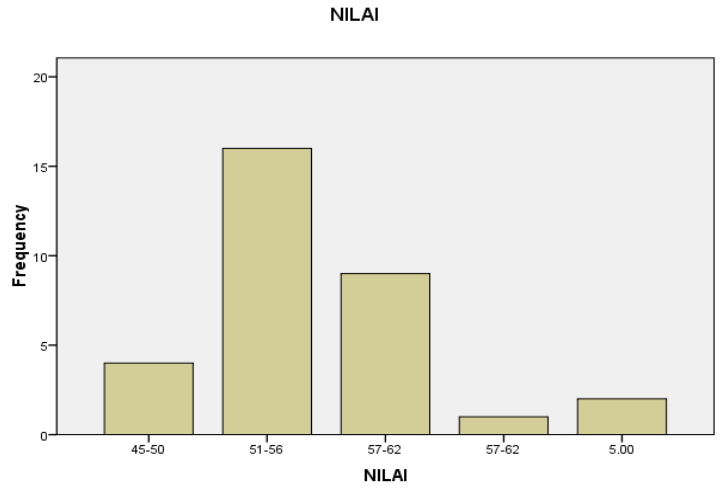

Gambar 1. Histogram Motivasi Siswa

Tabel 5, kategori kecenderungan

frekuensi untuk variabel motivasi siswa pembelajaran pendidikan jasmani berbasis online di SMA Angkasa 1 Lanud Soewondo termasuk dalam kategori sedang. (Suprihatin, 2015) untuk menumbuhkan motivasi belajar siswa yaitu dengan mengembangkan kemampuan serta keinginan dari siswa dalam mengikuti pelajaran. Salah satu upaya yang dilakukan untuk bisa memberikan motivasi kepada siswa melalui pengalaman belajar kemudian di evaluasi agar dapat diberikan motivasi yang sesuai dengan kondisi masing-masing siswa.

Tabel 6. Kecenderungan Frekuensi Variabel Motivasi Siswa Kelas XI IPA 1 dalam Mengikuti Pembelajaran Pendidikan Jasmani Berbasis Online di SMA Angkasa 1 Lanud Soewondo

\begin{tabular}{clccc}
\hline No & \multicolumn{1}{c}{ Kategori } & Interval & Frekuensi & Frekuensi Relatif $(\%)$ \\
\hline 1. & Tinggi & $\mathrm{X} \geq 73.333$ & 9 & 28,13 \\
2. & Sedang & $73.333>\mathrm{X} \geq 62.5$ & 20 & 62,50 \\
3. & Rendah & $62.5>\mathrm{X} \geq 51.667$ & 3 & 9,38 \\
4. & Sangat Rendah & $\mathrm{X} \leq 51.667$ & 0 & 0,00 \\
\hline & & 32 & 100,00 \\
\hline
\end{tabular}




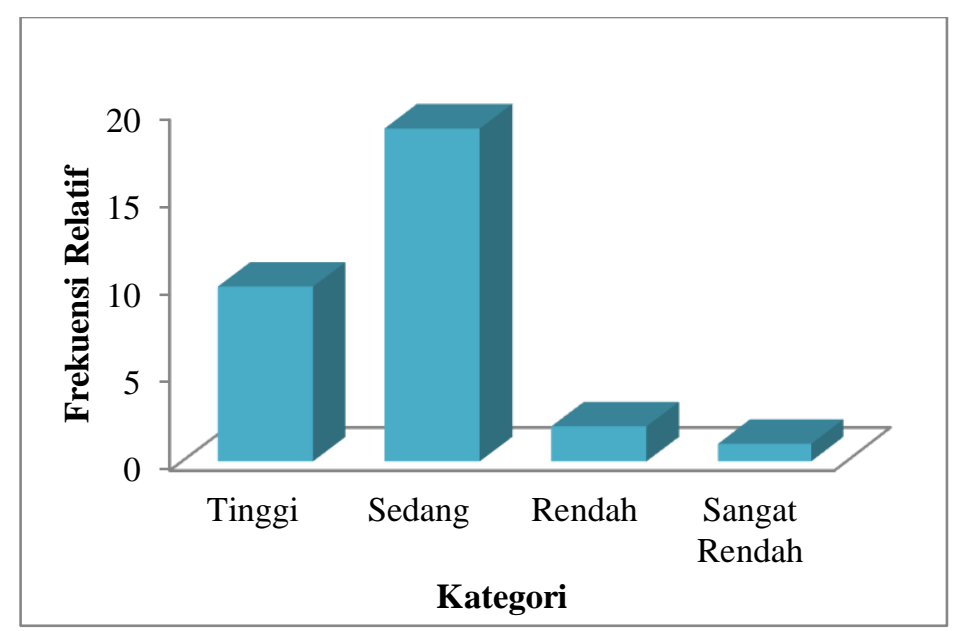

Gambar 2. Histogram kategorisasi Variabel Motivasi Siswa Kelas XI IPA 1 di SMA Angkasa 1 Lanud Soewondo

Pada tabel 6 dan gambar 2 terlihat dari 32 orang siswa yang mengikuti pembelajaran berbasis online, dimana terdapat hasil motivasi dengan kategori tinggi sebanyak 9 orang $(28,13 \%)$, kategori sedang sebanyak 20 orang siswa $(62,50 \%)$, kategori rendah sebanyak 3 orang $(9,38 \%)$. Sehingga dapat disimpulkan bahwa motivasi siswa kelas XI IPA 1 SMA Angkasa 1 Lanud Soewondo dalam mengikuti pembelajaran berbasis online termasuk dalam kategori sedang.

Pembelajaran dengan berbantuan media pembelajaran dapat memberikan keleluasaan pada siswa untuk belajar sendiri sesuai dengan kemampuan dan gaya belajar masingmasing. Penggunaan media pembelajaran akan dapat meningkatkan rasa ketertarikan dan keaktifan interaksi, dikarenakan meningkatkan kualitas hasil belajar sehingga akan menumbuhkan sikap positif yang berasal dari siswa (Pebruanti dan Munadi, 2015). Setelah mengkategorikan setiap pernyataan tentang Motivasi kemudian dikelompokkan dan dirata-rata untuk mengkategorikan setiap indikator motivasi siswa. Secara rinci berikut akan dideskripsikan data mengenai masing masing faktor dan indikator yang mendasari motivasi siswa kelas XI dalam mengikuti pembelajaran pendidikan jasmani berbasis online di SMA Angkasa 1 Lanud Soewondo.

\section{Pengaruh Faktor Intrinsik}

Faktor intrinsik merupakan salah satu faktor yang terdapat dalam motivasi siswa kelas XI IPA 1 dalam mengikuti pembelajaran pendidikan jasmani berbasis online pada SMA Angkasa 1 Lanud Soewondo. Pada penelitian ini, faktor intrinsik terdiri dari 4 indikator yaitu kesehatan, perhatian, minat, dan bakat. Dalam penelitian ini faktor intrinsik dijabarkan ke dalam 19 item pertanyaan. Dari 19 butir pertanyaan tersebut telah di uji validitas, dan telah dinyatakan valid dan layak untuk digunakan sebagai instrumen penelitian motivasi siswa kelas XI dalam mengikuti pembelajaran pendidikan jasmani berbasis online di SMA Angkasa 1 Lanud Soewondo.

Hasil penelitian memperoleh nilai maksimum sebesar 76 dan nilai minimum 50. Rerata diperoleh sebesar 56,47 dan standar deviasi 5,81 nilai median diperoleh sebesar 56 dan modus sebesar 50. Selanjutnya data dikategorikan sesuai dengan rumus 
yang telah ditentukan menjadi 4 kategori, yaitu kategori sangat rendah, rendah, tinggi dan sangat tinggi berdasarkan nilai mean dan standar deviasi. Tabel 7 merupakan penghitungan norma kategori motivasi siswa kelas XI IPA 1 dalam mengikuti pembelajaran pendidikan jasmani berbasis online di SMA Angkasa 1 Lanud Soewondo berdasarkan faktor intrinsik.

Tabel 7. Penghitungan Normatif Kategorisasi Motivasi Siswa Kelas XI IPA 1 Berdasarkan Faktor Intrinsik.

\begin{tabular}{ccc}
\hline Formula & Batasan & Kategori \\
\hline $\mathrm{Mi}+1,5 \mathrm{SDi}<\mathrm{X} \leq \mathrm{Mi}+3 \mathrm{SDi}$ & $61,75<\mathrm{X} \leq 76$ & Tinggi \\
$\mathrm{Mi}<\mathrm{X} \leq \mathrm{Mi}+1,5 \mathrm{Sdi}$ & $47,5<\mathrm{X} \leq 61,75$ & Sedang \\
$\mathrm{Mi}-1,5 \mathrm{SDi}<\mathrm{X} \leq \mathrm{Mi}$ & $33,25<\mathrm{X} \leq 47,5$ & Rendah \\
$\mathrm{Mi}-3 \mathrm{SDi}<\mathrm{X} \leq \mathrm{Mi}-1,5 \mathrm{Sdi}$ & $19<\mathrm{X} \leq 33,25$ & Sangat Rendah \\
\hline
\end{tabular}

Keterangan: $\mathrm{X}=$ jumlah skor subjek, $\mathrm{Mi}=$ rerata idealideal $=56,47$

SDi $=$ simpangan baku ideal $=9,5$

Mengacu pada kategorisasi kecenderungan yang telah dihitung tersebut, maka distribusi frekuensi motivasi siswa kelas XI dalam mengikuti pembelajaran pendidikan jasmani pada SMA Kota berdasarkan faktor intrinsik dapat diketahui. Tabel 7 berikut merupakan distribusi frekuensi motivasi siswa kelas XI IPA 1 dalam mengikuti pembelajaran pendidikan jasmani berbasis online di SMA Angkasa 1 Lanud Soewondo berdasarkan faktor intrinsik.

Tabel 8. Distribusi Frekuensi Motivasi Siswa Kelas XI IPA 1 Berdasarkan Faktor Intrinsik

\begin{tabular}{ccccc}
\hline No & Kelas Interval & Kategori & Frekuensi & Persentase (\%) \\
\hline 1. & $61,75<\mathrm{X} \leq 76$ & Tinggi & 7 & 21,88 \\
2. & $47,5<\mathrm{X} \leq 61,75$ & Sedang & 23 & 71,88 \\
3. & $33,25<\mathrm{X} \leq 47,5$ & Rendah & 2 & 6,25 \\
4. & $19<\mathrm{X} \leq 33,25$ & Sangat Rendah & 0 & 0,00 \\
\hline & Total & & 32 & 100,00 \\
\hline
\end{tabular}

Tabel 8 diperoleh motivasi siswa kelas XI IPA 1 dalam mengikuti pembelajaran pendidikan jasmani berbasis online di SMA Angkasa 1 Lanud Soewondo berdasarkan faktor intrinsik yaitu kategori tinggi sebanyak 7 orang $(21,88 \%)$, kategori sedang sebanyak 23 orang $(71,88 \%)$, kategori rendah sebanyak 2 orang $(6,25 \%)$. Sehingga dapat disimpulkan bahwa faktor intrinsik terhadap motivasi termasuk dalam kategori sedang.
Apabila digambarkan dalam bentuk histogram, berikut gambar histogram yang diperoleh: 


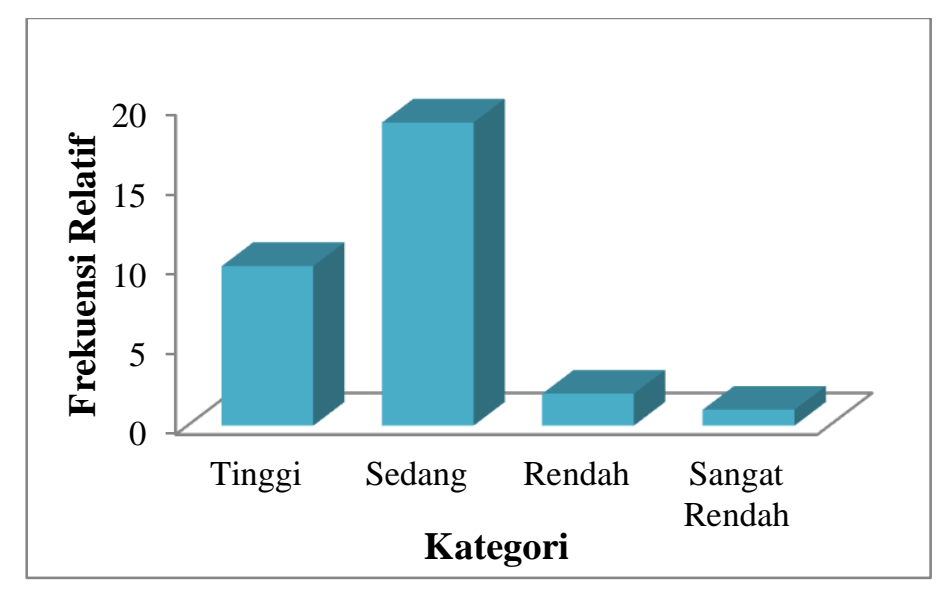

Gambar 3. Histogram Motivasi Siswa Kelas XI IPA 1 dalam Mengikuti Pembelajaran

Pendidikan Jasmani Berbasis Online di SMA Angkasa 1 Lanud Soewondo

Indikator faktor intrinsik untuk motivasi siswa pada penelitian ini yaitu kesehatan, perhatian, minat, bakat.

\section{a. Kesehatan}

Kesehatan merupakan indikator untuk menggambarkan faktor instrinsik motivasi siswa kelas XI IPA 1 dalam mengikuti pembelajaran pendidikan jasmani berbasis online. Hasil diperoleh bahwa siswa memiliki motivasi dengan kategori tinggi sebanyak 8 orang siswa (25\%), kategori sedang sebanyak 23 orang $(71,88 \%)$, kategori rendah 1 orang $(3,13)$. Sehingga disimpulkan berdasarkan faktor kesehatan termasuk dalam kategori sedang.

\section{b. Perhatian}

Motivasi siswa berdasarkan faktor perhatian diperoleh hasil yaitu sebanyak 13 orang siswa $(40,63 \%)$ termasuk dalam kategori tinggi, sebanyak 17 orang siswa $(53,13 \%)$ termasuk dalam kategori sedang, sebanyak 2 orang $(6,25 \%)$ termasuk dalam kategori rendah. Sehingga indikator perhatian siswa termasuk dalam kategori sedang.

\section{c. Minat}

Hasil diperoleh bahwa siswa memiliki motivasi dengan kategori tinggi sebanyak 7 orang siswa
$(53,13 \%)$, kategori sedang sebanyak 14 orang $(43,75 \%)$, kategori rendah 1 orang $(3,13)$. Sehingga disimpulkan berdasarkan faktor kesehatan termasuk dalam kategori tinggi.

\section{d. Bakat}

Hasil diperoleh bahwa siswa memiliki motivasi dengan kategori tinggi sebanyak 7 orang siswa $(21,88 \%)$, kategori sedang sebanyak 25 orang $(78,13 \%)$. Sehingga disimpulkan berdasarkan faktor kesehatan termasuk dalam kategori sedang.

\section{Pengaruh Faktor Ekstrinsik}

Faktor ekstrinsik merupakan motivasi yang berasal dari luar diri individu. Motivasi memiliki peranan yang penting dalam mendorong kesuksesan belajar mahasiswa (Handayani, 2017). Pada penelitian ini, faktor ekstrinsik dijabarkan ke dalam 3 item tes dengan skor 1-4, sehingga diperoleh hasil skor minimum ideal $1 \mathrm{x}$ 16 sebesar 16, skor maksimum ideal $4 \mathrm{x}$ 16 sebesar 64. Hasil pengkategorian data motivasi mengikuti pembelajaran pendidikan jasmani berbasis online berdasarkan faktor ekstrinsik siswa dapat dilihat pada tabel 9 . 
Tabel 9. Kategorisasi Data Motivasi Mengikuti Pembelajaran Pendidikan Jasmani Berbasis Online Berdasarkan Faktor Ekstrinsik

\begin{tabular}{ccccc}
\hline No & Interval Kelas & F & F \%) & Kategori \\
\hline 1 & $52-64$ & 6 & 18,75 & Tinggi \\
2 & $40-51$ & 19 & 59,38 & Sedang \\
3 & $28-39$ & 5 & 15,63 & Rendah \\
4 & $16-27$ & 2 & 6,25 & Sangat Rendah \\
\hline & Total & 32 & 100,00 & \\
\hline
\end{tabular}

Tabel 9 diperoleh motivasi siswa kelas XI IPA 1 dalam mengikuti pembelajaran pendidikan jasmani berbasis online di SMA Angkasa 1 Lanud Soewondo berdasarkan faktor ekstrinsik yaitu kategori tinggi sebanyak 6 orang $(18,75 \%)$, kategori sedang sebanyak 19 orang $(59,38 \%)$, kategori rendah sebanyak 5 orang $(15,63 \%)$, kategori sangat rendah sebanyak 2 orang siswa $(6,25 \%)$. Sehingga dapat disimpulkan bahwa faktor ekstrinsik terhadap motivasi termasuk dalam kategori sedang. Apabila digambarkan dalam bentuk histogram, berikut gambar 4 histogram yang diperoleh:

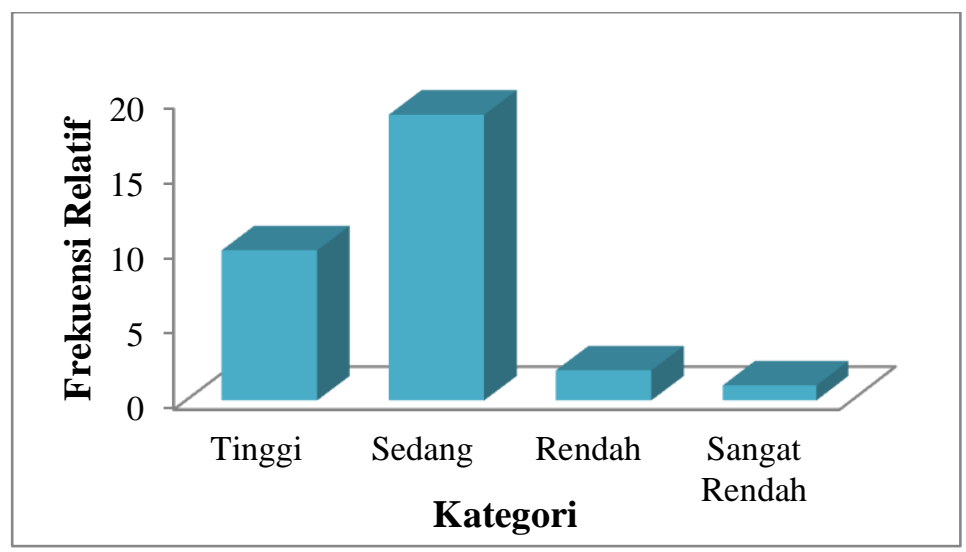

Gambar 4. Histogram Motivasi Mengikuti Pembelajaran Pendidikan Jasmani Berbasis Online Berdasarkan Faktor Ekstrinsik

Indikator pada faktor ekstrinsik yaitu metode mengajar,

\section{a. Metode Mengajar}

Hasil diperoleh bahwa siswa memiliki motivasi dengan kategori tinggi sebanyak 9 orang siswa $(28,13 \%)$, kategori sedang sebanyak 18 orang $(56,26 \%)$, kategori rendah 4 orang (12,50), kategori sangat rendah sebanyak 1 orang $(3,13 \%)$. Sehingga disimpulkan berdasarkan faktor metode mengajar termasuk dalam kategori sedang.

\section{b. Fasilitas Pembelajaran}

Fasilitas pembelajaran sangat mempengaruhi dalam pembelajaran secara online. Hasil diperoleh bahwa siswa memiliki motivasi dengan kategori tinggi sebanyak 10 orang siswa $(31,25 \%)$, kategori sedang sebanyak 19 orang $(59,38 \%)$, kategori rendah 2 orang $(6,25 \%))$, kategori sangat rendah sebanyak 1 orang $(3,13 \%)$. Sehingga disimpulkan berdasarkan fasilitas pembelajaran termasuk dalam kategori sedang. 
Dalam proses pembelajaran, pemanfaatan falitas belajar yang baik juga menentukan motivasi belajar dalam proses pembelajaran online. Pembelajaran online memerlukan fasilitas yang menunjang pembelajaran seperti internet, computer atau gawai. Pemanfaatan fasilitas yang baik akan memaksimalkan materi yang akan di sampaikan dengan memaksimalkanfungsi fasilitas yang ada.

Pihak sekolah diharapkan memberikan dukungan yang optimal untuk mendukung pembelajaran onlineyang dilaksanakan oleh para gurunya. seperti penggadaan sumber belajar, komputer yang tersambung dengan internet, dan alat-alat yang mendukung kegiatan pembelajaranbagi para guru. Sarana prasarana tersebut digunakan untuk mencari pengetahuan dan informasi dari berbagai sumber.

\section{c. Penggunaan Media}

Hasil diperoleh bahwa siswa memiliki motivasi dengan kategori tinggi sebanyak 10 orang siswa (31,25\%), kategori sedang sebanyak 19 orang $(59,38 \%)$, kategori rendah 2 orang $(6,25 \%))$, kategori sangat rendah sebanyak 1 orang $(3,13 \%)$. Sehingga disimpulkan berdasarkan penggunaan media termasuk dalam kategori sedang.

\section{d. Kondisi Lingkungan}

Hasil diperoleh bahwa siswa memiliki motivasi dengan kategori tinggi sebanyak 7 orang siswa (21,88\%), kategori sedang sebanyak 25 orang $(78,13 \%)$. Sehingga disimpulkan berdasarkan faktor kondisi lingkungan termasuk dalam kategori sedang.

\section{SIMPULAN DAN SARAN \\ Simpulan}

Hasil penelitian dapat disimpulkan bahwa siswa mempunyai motivasi sedang terhadap pembelajaran pendidikan jasmani berbasis online. Motivasi sedang tersebut dapat menjadi pendorong bagi siswa untuk dapat meningkatkan motivasi siswa dalam pembelajaran pendidikan jasmani. Dikarenakan dengan motivasi yang sedang, dapat ditingkatkan menjadi tinggi. sehingga walaupun belajar secara online, siswa dapat tetap bersemangat untuk menerima pelajaran yang diberikan oleh guru.

\section{Saran}

Adapun saran yang berikan agar siswa dan sekolah saling berkomunikasi dengan baik selama kegiatan pembelajaran online tersebut. Agar materi yang diberikan dapat menumbuhkan motivasi bagi siswa untuk tetap bersemangat mengikuti kelas online. Guru dapat memberikan materi yang menarik bagi siswa, agar siswa tetap betah dan dapat menyelesaikan setiap tugas yang diberikan.

\section{DAFTAR PUSTAKA}

Adawi, R. (2008). Pembelajaran Berbasis E-Learning. Jurnal Bahas Unimed.

Adiat, K. A. N., Nawawi, M. N. M. Abdullah, K. (2012). Assessing the accuracy of GIS-based elementary multi criteria decision analysis as a spatial prediction tool - A case of predicting potential zones of sustainable groundwater resources. Journal of Hydrology. doi: 10.1016/j.jhydrol.2012.03.028.

Arnesti, N. Hamid, A. (2015). Penggunaan Media Pembelajaran Online - Offline Dan Komunikasi Interpersonal Terhadap Hasil Belajar Bahasa Inggris. Jurnal Teknologi 
Informasi \& Komunikasi Dalam Pendidikan. doi: 10.24114/jtikp.v2i1.3284.

Dabbagh, N. (2005). Pedagogical models for E-Learning: A theory-based design framework. International Journal of Technology in Teaching and Learning.

Emda, A. (2018). Kedudukan Motivasi Belajar Siswa Dalam Pembelajaran. Lantanida Journal. doi: 10.22373/lj.v5i2.2838.

Fauziah, A., Rosnaningsih, A. Azhar, S. (2017). Hubungan Antara Motivasi Belajar Dengan Minat Belajar Siswa Kelas Iv Sdn Poris Gaga 05 Kota Tangerang. Jurnal JPSD (Jurnal Pendidikan Sekolah Dasar). doi: 10.26555/jpsd.v4i1.a9594.

Hapsari, S. A. and Pamungkas, H. (2019). Pemanfaatan Google Classroom Sebagai Media Pembelajaran Online di Universitas Dian Nuswantoro. WACANA: Jurnal Ilmiah Ilmu Komunikasi. doi: 10.32509/wacana.v18i2.924.

Jannah, P. Z. (2014). Pengaruh Media Pembelajaran Zooming Presentation Terhadap Hasil belajar Siswa Kelas X pada Konsep Suhu dan Kalor. Skripsi.

Kompri (2015). Motivasi Pembelajaran Perspektif Guru dan Siswa., Konsep Motivasi.

Mediawati E. 2010. Pengaruh Motivasi Belajar Mahasiswa Dan Kompetensi Dosen Terhadap Prestasi Belajar. Jurnal Pendidikan Ekonomi Dinamika Pendidikan,10(2), 134 - 146

Muhammad, M. (2017). Pengaruh Motivasi Dalam Pembelajaran.
Lantanida Journal. doi: 10.22373/lj.v4i2.1881.

Pebruanti, L. Munadi, S. (2015). Peningkatan Motivasi Dan Hasil Belajar Pada Mata Pelajaran Pemograman Dasar Menggunakan Modul Di Smkn 2 Sumbawa. Jurnal Pendidikan Vokasi. doi: 10.21831/jpv.v5i3.6490.

Rokhayati, A. (2016). Implementasi Pendekatan Taktis dalam Pembelajaran Pendidikan Jasmani Terhadap Motivasi, Kebugaran Jasmani dan Kemampuan Motorik. Jurnal Pendidikan Jasmani Dan Olahraga. doi: 10.17509/jpjo.v1i2.5664.

Sadirman (2011). Keguruan dan Ilmu Kependidikan. Interakasi dan motivasi Belajar-Mengajar.

Soni et al. (2018). Optimalisasi Pemanfaatan Google Classroom Sebagai Media Pembelajaran Di SMK Negeri 1 Bangkinang. Jurnal Pengabdian Untuk Mu NegeRI.

Sudarsana, I. K. (2016). Peningkatan Mutu Pendidikan Luar Sekolah Dalam Upayapembangunan Sumber Daya Manusia. Jurnal Penjaminan Mutu. doi: 10.25078/jpm.v1i1.34.

Suprihatin, S. (2015). Upaya Guru Dalam Meningkatkan Motivasi Belajar Siswa. Promosi (Jurnal Pendidikan Ekonomi). doi: 10.24127/ja.v3i1.144.

Syah, M. (2010) Psikologi Pendidikan dengan pendekatan Baru, Psikologi Pendidikan dengan pendekatan Baru.

Uno, B. H. (2014). Teori Motivasi \& Pengukurannya', Personnel Review. 